\title{
Uji Biokompatibilitas Serbuk Limbah Cangkang Cue (Faunus ater) Sebagai Bahan Implan Tulang (Bone Graft) pada Kelinci
}

\author{
[BIOCOMPATIBILITY TEST OF CUE SHELL WASTE POWDER \\ (FAUNUS ATER) AS THE BONE GRAFT IN RABBITS] \\ Astri Wulandari ${ }^{1}$, Erwin Erwin ${ }^{2 *}$, Rusli Rusli ${ }^{2}$, \\ Amiruddin Amiruddin², Sugito Sugito², \\ Ummu Balqis $^{3}$, Mustafa Sabri ${ }^{4}$, Sri Wahyuni ${ }^{4}$ \\ ${ }^{1}$ Mahasiswa S2 Kesehatan Masyarakat Veteriner, \\ ${ }^{2}$ Laboratorium Klinik dan Bedah \\ ${ }^{3}$ Laboratorium Patologi, ${ }^{4}$ Laboratorium Anatomi, \\ Fakultas Kedokteran Hewan Universitas Syiah Kuala \\ Jl. Tengku Hasan Krueng Kalee No. 4, \\ Banda Aceh, Aceh, Indonesia, 23111 \\ Telp +6265117551536; Fax +6265117551536; \\ Email: erwin2102@unsyiah.ac.id
}

\begin{abstract}
ABSTRAK
Bahan implan tulang (bone graft) berbahan dasar alam saat ini mulai banyak dikembangkan. Penelitian ini bertujuan untuk menguji biokompatibilitas serbuk limbah cangkang cue (Faunus ater) sebagai kandidat bahan implan tulang pada kelinci berdasarkan pengamatan gambaran klinis otot, densitas radiografi, histopatologi tulang dan otot. Penelitian ini menggunakan enam ekor kelinci jantan berusia 8-10 bulan dengan bobot badan 1,5-2,0 kg. Tindakan bedah dilakukan secara steril dan aseptis dengan membuat defek area diaphysis tulang femur berdiameter $5 \mathrm{~mm}$ mencapai sumsum tulang. Kelompok perlakuan I (P1) diinfiltrasi $\mathrm{NaCl}$ 0,9\% dan kelompok perlakuan II (P2) diberikan serbuk cangkang cue sebanyak 0,25 g. Pengamatan radiografi dilakukan pada hari ke-15, 30, 45, dan 60 setelah perlakuan dengan mengamati integrated density area implan dan area sekeliling implan. Hari ke-60 setelah perlakuan, semua kelinci dikorbankan nyawanya degan cara dieutanasi untuk pembuatan sediaan histopatologi dalam parafin blok. Integrated density material implan dan area sekeliling implan menunjukkan densitas radiopaque yang berbeda siginifikan antar kelompok perlakuan dan berfluktuasi di antara waktu pengamatan dengan perbedaan signifikan. Pengamatan histopatologi otot sekitar implan menunjukkan sel inflamasi, nekrosis dan jaringan ikat, sedangkan tulang sekitar implan menunjukkan proliferasi jaringan ikat, neovaskularisasi, proliferasi bone marrow, pertumbuhan tulang baru dan sel inflamasi. Serbuk cangkang cue memiliki biokompatibilitas yang baik dan berpotensi untuk dikembangkan menjadi bone graft.
\end{abstract}

Kata-kata kunci: bone graft; cangkang cue; Faunus ater; biokompatibilitas

\begin{abstract}
Natural-based bone grafts are currently being developed. This study aims to examine the biocompatibility of Faunus ater (cue) shell waste powder as bone graft in rabbits based on clinical observation of muscle, radiographic density, histopathology of bone and muscle. The study used 6 male rabbits aged 8-10 months and weighted 1.5-2 kg. Surgery was performed in a sterile and aseptic manner by making a defect in the diaphysis area of the femur with diameter of $5 \mathrm{~mm}$ until the bone marrow was exposed. Treatment group I (P1) was infiltrated by $0.9 \% \mathrm{NaCl}$ and treatment group II (P2) was given 0.25 $\mathrm{g}$ of cue shell powder into the defect. Radiographic observations on day 15, 30, 45, and 60 after treatment was done by observing the integrated density of the implant area and the areaaround the implant. The 60th day after treatment, all rabbits were euthanized for histopathological preparations in paraffin blocks. Integrated density of graft material and around the implant site showed a radiopaque density
\end{abstract}


that was significantly different between the treatment group and fluctuated among observation times with significant differences. Histopathological findings of the muscle around the implant showed inflammatory cells, necrosis and connective tissue, while the bone around the implant showed connective tissue proliferation, neovascularization, bone marrow proliferation, new bone growth and inflammatory cells. Cue shell powder has good biocompatibility and potentially to be developed into bone graft.

Keywords: bone graft; cue shell; Faunus ater; biocompatibility

\section{PENDAHULUAN}

Faunus ater dalam bahasa Aceh dikenal dengan "cue" adalah siput makrozoobentos yang hidup di perairan Aceh dan beberapa daerah di Indonesia. Cue kerap kali diolah menjadi makanan khas dan menjadi kegemaran masyarakat di Aceh. Bagian cue yang dikonsumsi hanya isi dalamnya, sedangkan cangkangnya menjadi limbah (Agustina et al., 2017). Limbah cangkang hewan lunak seperti siput dan kerang banyak terdapat di daerah perairan dan rumah makan. Pemanfaatan limbah cangkang hewan lunak sebagai material implan mulai banyak diteliti (Mo et al., 2018).Material implan yang digunakan sebagai bone graft pada dasarnya memiliki sifat yang mirip seperti tulang yang berasal dari donor hidup, donor post mortem, ataupun bahanbahan sintetik. Aplikasi bone graft bertujuan untuk menyambung dan mempercepat proses kesembuhan jaringan tulang (Dahiya et al., 2019). Limbah cangkang cue memiliki kandungan kitin dan kalsium (Ca) yang dapat dimanfaatkan untuk bahan dasar kitosan sebagai nano biokoagulan (Wijaya et al., 2017), bahan dasar hidroksiapatit (HA) sebagai biosorben ion logam, penjernih air gambut dan sebagai kandidat material implan bone graft (Alif et al., 2017; Asfi et al., 2019; Jamil dan Ridwan, 2019). Sumber alami HA di antaranya tulang mamalia (tulang sapi), batu karang, cangkang telur dan cangkang hewan lunak (Fitriawan, 2014).

Penelitian tentang pemanfaatan limbah cangkang cue sebagai bahan dasar bone graft belum pernah dilakukan. Penelitian ini bertujuan mengembangkan HA alami berasal dari limbah cangkang cue sebagai kandidat bone graft melalui pengujian in vivo pada hewan percobaan.

\section{METODE PENELITIAN}

\section{Ethical Approval}

Penelitian ini telah mendapat izin pelaksanaan penelitian dari Komisi Etik Penggunaan Hewan untuk Penelitian, Fakultas Kedokteran
Hewan Universitas Syiah Kuala dengan Nomor. 48/KEPH/X/2019.

\section{Prosedur Penelitian}

Limbah cangkang cue dikumpulkan dari rumah makan di seputaran Banda Aceh dan Aceh Besar untuk selanjutnya dicuci dengan air dan dikeringkan. Setelah kering cangkang cue dihancurkan sampai halus kemudian diayak menggunakan ayakan dengan ukuran pori 100 mesh. Serbuk cangkang cue ditimbang sebanyak $20 \mathrm{~g}$, kemudian dimasukkan ke dalam kertas perkamen untuk selanjutnya disterilkan dengan oven (Cool vacuum oen $\mathrm{VOcool}^{\circledR}$, Memmerth $\mathrm{GmbH}+\mathrm{Co}$. KG, Scwabach, Jerman) dengan suhu $170^{\circ} \mathrm{C}$ selama dua jam. Pemeriksaan kandungan mineral cangkang cue dilakukan dengan metode Atomic Absorption Spectophotometry (AAS). Metode AAS secara garis besar meliputi proses destruksi sampel, pembuatan larutan standar mineral yang akan diuji, pengenceran sampel, dan analisis menggunakan mesin AAS (Suryaningsih et al., 2018).

Penelitian ini menggunakan enam ekor kelinci jantan New Zealand White berusia 8-10 bulan dengan bobot badan 1,5-2,0 kg yang dibagi menjadi dua kelompok perlakuan. Kelompok perlakuan I (P1) diinfiltrasi $\mathrm{NaCl} 0,9 \%$ dan kelompok perlakuan II (P2) diberikan serbuk cangkang cue sebanyak $0,25 \mathrm{~g}$. Pemeliharaan hewan coba dilakukan pada kandang persegi dengan ukuran $50 \mathrm{~cm} \times 50 \mathrm{~cm} \times 50 \mathrm{~cm}$ untuk setiap individu. Material kandang berupa papan kayu dan kawat. Hewan coba diaklimatisasi selama dua minggu disertai pemberian antibiotik ciprofloxacin (Ciprofloxacin 500 mg ${ }^{\circledR}$, Novapharin, Gresik, Indonesia) dengan dosis 15 $\mathrm{mg} / \mathrm{kg}$ BB dua kali sehari selama enam hari dan antiparasit ivermectin (Wormectin ${ }^{\circledR}$, Medion, Bandung, Indonesia) dosis $0,3 \mathrm{mg} / \mathrm{kg} \mathrm{BB}$ sub cutaneous (SC) dengan sekali pemberian (Atakisi et al., 2009). Selama masa pemeliharaan, hewan coba diberi pakan komersial (SKR 214, Sarang Kelinci Rabbitry, Sukabumi, Indonesia) dan air minum secara ad libitum.

Kelinci dipuasakan selama delapan jam 
sebelum operasi untuk menghindari efek samping anestesi, kemudian diberi premedikasi atropin sulfat (Atropin ${ }^{\circledR}$, Ethica, Bekasi, Indonesia) dosis $0,05 \mathrm{mg} / \mathrm{kg} \mathrm{BB} \mathrm{SC}$ dan anestesi ketamine (Ketamin ${ }^{\circledR}$, Troy Laboratories PTY Limited, Gendening NSW, Australia) dosis 35 $\mathrm{mg} / \mathrm{kg}$ BB intra muscular (IM) dan xylazine (Xyla $^{\circledR}$, Interchemie, Vanray, Belanda) dosis 2 $\mathrm{mg} / \mathrm{kg}$ BB IM (Plumb, 2018). Rambut area lateral femur dexter dicukur dan pembedahan dilakukan secara steril dan aseptis. Area yang akan disayat didesinfeksi dengan alkohol 70\% dan iodin 3\%. Kulit area femuralis disayat, tepat di atas $m$. vastus lateralis, kemudian otot dipreparir dan dikuakkan menggunakan retraktor hingga tampak tulang femur. Tulang femur dibuat defek dengan cara dibor hingga mencapai sumsum tulang dengan diameter 5 $\mathrm{mm}$ (Wirata et al., 2018). Defek dibilas dengan $\mathrm{NaCl}$ 0,9\% dan dibiarkan sembuh sendiri (P1), sedangkan P2 diimplan dengan serbuk cangkang cue sebanyak 0,25 g. Musculus vastus lateralis yang terpisah dengan fascia digabungkan dengan jahitan pola simple continuous menggunakan benang jahit operasi chromic catgut (Chromic catgut 3.0 USP $^{\circledR}$, GEA, Jakarta, Indonesia). Kulit dijahit dengan pola simple interrupted menggunakan benang jahit operasi silk (Silk 3.0 USP ${ }^{\circledR}$, GEA, Jakarta, Indonesia). Pemberian obat-obatan pascaoperasi dua kali sehari selama lima hari yaitu antibiotik doxycycline (Doxycycline ${ }^{\circledR}$, PT. Indo Farma, Bekasi, Indonesia) $10 \mathrm{mg} / \mathrm{kg} \mathrm{BB}$ per oral (PO), antiinflamasi meloxicam (Meloxicam ${ }^{\circledR}$, Kimia Farma, Jakarta, Indonesia) 0,2 mg/kg BB PO, vitamin C (Vitamin $\mathrm{C}^{\circledR}$, Kimia Farma, Jakarta, Indonesia) $100 \mathrm{mg} / \mathrm{kg}$ BB PO

\section{Pengamatan Radiografi}

Hewan diposisikan rebah kesampig kiri (left lateral recumbency) kemudian diambil gambaran tulang pada bagian yang diimplan dengan nilai $55 \mathrm{kVp}$ dan $30 \mathrm{mAs}$ (Wirata et al., 2018) menggunakan mesin rontgent (Tube Collimator Multix Fusion ${ }^{\circledR}$, Siemens ${ }^{\mathrm{TM}}$, Berlin, Jerman) dan kaset (Direct Radiography ${ }^{\circledR}$, AgfaGevaert, Westerlo, Belgia). Hasil rontgent berupa soft copy dianalisis integrated density (densitas) area sekitar implan dan defek yang diimplan diukur menggunakan software digital ImageJ (Public Domain). Pengamatan radiografi dilakukan pada hari ke-0 (sebelum perlakuan), 15, 30, 45, dan 60 setelah perlakuan. Pengamatan hari ke-0 sebelum perlakuan untuk mengamati kondisi normal tulang femur kelinci.

\section{Pengamatan Histopatologi}

Hari ke-60 setelah implan, semua kelinci dikorbankan nyawanya dengan cara dieutanasi untuk pengambilan tulang femur, tulang femur area defek dan otot sekitarnya diambil dengan potongan transversal untuk pembuatan sediaan histopatologi. Selanjutnya difiksasi dalam Buffered Neutral Formaline (BNF) 10\%, selanjutnya tulang didekalsifikasi. Pembuatan sediaan mikroteknik mengunakan metode paraffin block dan diiris dengan mikrotom dengan ketebalan 6 ìm. Sediaan histologis diwarnai dengan pewarnaan hematoksilin-eosin (HE) untuk mengetahui gambaran histologis struktur tulang dan otot. Pengamatan sediaan histopatologi menggunakan mikroskop cahaya binokuler (Olympus CX23 $3^{\circledR}$, Olympus Co, Tokyo, Jepang). Setiap slide diamati sebanyak 10 lapang pandang. Parameter yang diamati untuk sampel otot antara lain kepadatan otot, respon inflamasi, nekrosis, dan jaringan ikat, sedangkan untuk sampel tulang parameternya adalah proliferasi jaringan ikat, pertumbuhan tulang baru, proliferasi bone marrow, neovaskularisasi, reaksi inflamasi, dan nekrosis. Anotasi skoring dengan simbol (-) tidak ditemukan, (+) sedikit, dan (++) banyak.

\section{Analisis Data}

Data hasil pemeriksaan kandungan mineral dan pengamatan histopatologi dianalisis secara deskriptif, sedangkan data hasil pengamatan integrated density dianalisis dengan sidik ragam taraf $95 \%$ menggunakan program SPSS 22.

\section{HASIL DAN PEMBAHASAN}

\section{Kandungan Mineral Serbuk Cangkang Cue}

Pemeriksaan mineral cangkang cue menggunakan metode Atomic Absorption Spectophotometry (AAS). Kandungan kalsium (Ca) serbuk cangkang cue mencapai 21,652 mg/ $\mathrm{g}$, sedangkan kandungan besi $(\mathrm{Fe})$ sebesar 0,254 $\mathrm{mg} / \mathrm{g}$. Cangkang cue mengandung kalsium yang tinggi dalam bentuk kalsium karbonat $\left(\mathrm{CaCO}_{3}\right)$ sehingga dapat dijadikan sebagai sumber kalsium untuk pembuatan bone graft biokeramik (Asfi et al., 2019). Kalsium merupakan salah satu unsur mineral pembentuk tulang, sebagian besar terdapat pada tulang dan gigi. Kalsium ini tersimpan dalam bentuk HA dan berperan pada proses mineralisasi jaringan tulang sehingga mampu 
memberikan kekuatan pada rangka. Selain itu, kalsium dalam tulang rangka juga berfungsi sebagai reservoir ion $\mathrm{Ca}^{2+}$ untuk mempertahankan kadar kalsium darah (Nordin, 1997; Fischer et al., 2018). Zat besi berperan sebagai kofaktor enzim dalam proses sintesis matriks tulang kolagen. Peran zat besi sebagai kofaktor enzim 25-hydroxycholcalciferol hydroxylase yang terlibat dalam aktivasi vitamin $\mathrm{D}$, sehingga memengaruhi penyerapan kalsium (Palacios, 2006).

\section{Integrated Density Bahan Implan}

Hasil penelitian menunjukkan peningkatan integrated density pada kelompok P2 yang berbeda signifikan dengan kelompok P1. Ratarata integrated density kelompok P2 sebesar $4212,67 \pm 2,31$ pada hari ke-15 berbeda signifikan dengan hari ke- 45 sebesar 5134,33 $\pm 2,31$. Pada kelompok P1 menunjukkan perbedaan yang signifikan antar hari pengamatan ke-15, 30, 45, dan 60 dengan rata-rata integrated density sebesar $3288,67 \pm 1,56 ; \quad 3647,67 \pm 1,56$; $3774,33 \pm 1,55$ dan $4271,67 \pm 1,56$. Rataan integrated density material implan bone graft dengan serbuk cangkang cue yang dilakukan pengukuran menggunakan software ImageJ dapat dilihat pada Tabel 1. Integrated density material implan meningkat sejak hari ke-15, 30, 45, dan menurun di hari ke-60. Hal ini diduga karena implan yang berbentuk serbuk sehingga mudah terserap dan tergeser ke sekeliling, namun angka integrated density-nya masih tetap stabil. Hal ini menandakan material implan dapat diterima oleh jaringan sekitar dan mendukung proses kesembuhan tulang. Proses kesembuhan tulang diawali dengan fase hematom, inflamasi, granulasi, pembentukan kalus lunak dan kalus keras, serta remodelling yang dimulai sejak beberapa jam hingga beberapa bulan setelah terjadinya defek (Einhorn dan Gerstendfeld, 2014). Pada hari ke-30 sampai 45 merupakan fase pembentukan kalus, sedangkan pada hari ke-60 merupakan fase remodelling. Pada fase ini defek tulang sudah tertutup dengan jaringan tulang baru yang mengitari daerah defek (Solomon et al., 2010).

Rata-rata integrated density kelompok P1 memiliki nilai yang lebih rendah dibandingkan kelompok P2. Defek tulang kelompok P1 tidak diimplan dan tulang akan sembuh sendiri, sedangkan elompok P2 diimplan dengan serbuk cangkang cue. Radiografi area defek pada kelompok P1 memiliki opasitas radiolucent, sedangkan kelompok P2 radiopaque (Gambar
Tabel 1. Integrated density bahan implan yang digunakan dalam penelitian

\begin{tabular}{lrr}
\hline \multirow{2}{*}{$\begin{array}{l}\text { Waktu Penga- } \\
\text { matan(Hari) }\end{array}$} & \multicolumn{3}{c}{ Kelompok } \\
\cline { 2 - 3 } & \multicolumn{1}{c}{$\mathrm{P} 1$} & \multicolumn{1}{c}{ P2 } \\
\hline 15 & $3288,67 \pm 1,56^{\mathrm{a}^{\mathrm{a}^{*}}}$ & $4212,67 \pm 2,31^{\mathrm{a}+}$ \\
30 & $3647,67 \pm 1,56^{\mathrm{b}^{*}}$ & $4768,67 \pm 2,31^{\mathrm{a}+}$ \\
45 & $3774,33 \pm 1,55^{\mathrm{c}^{*}}$ & $5134,33 \pm 2,31^{\mathrm{b+}}$ \\
60 & $4271,67 \pm 1,56^{\mathrm{d}^{*}}$ & $4450,67 \pm 2,31^{\mathrm{ab}+}$ \\
\hline
\end{tabular}

Keterangan : Kelompok perlakuan I (P1) diinfiltrasi $\mathrm{NaCl}$ 0,9\% dan kelompok perlakuan II (P2) diberikan serbukcangkang cue sebanyak 0,25 g. Angka yang diikuti superskrip berbeda $(*+)$ pada baris yang sama menunjukkan perbedaan signifikan $(\mathrm{P}<0,05)$ antar kelompok perlakuan. Angka yang diikuti superskrip berbeda pada kolom yang sama (a-b-c-d) menunjukkan perbedaan signifikan diantara waktu pengamatan $(\mathrm{P}<0,05)$

2). Opasitas suatu jaringan ditentukan oleh kemampuan jaringan menyerap sinar-X. Penurunan volume tulang yang terjadi akibat defek menyebabkan integrated density-nya berkurang yang mengindikasikan berkurang pula kepadatan tulang tersebut, sehingga mampu ditembus oleh sinar-X (Thrall, 2013).

\section{Integrated Density Sekeliling Implan}

Hasil penelitian diperoleh rata-rata integrated density sekeliling implan pada kelompok P2 menunjukkan perbedaan yang signifikan dengan kelompok P1. Integrated density kelompok $\mathrm{P} 2$ mencapai 186,9 2 2,93 pada hari ke- 45 , tidak berbeda signifikan dengan hari ke-15, 30, dan 60 yaitu sebesar 179,20 2 ,93;

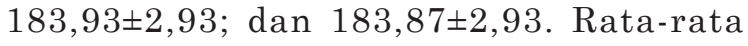
integrated density kelompok P1 mencapai $141,93 \pm 4,70$ pada hari ke-15 yang berbeda signifikan dengan hari ke-60 mencapai $165,07 \pm 4,70$. Rataan integrated density sekeliling implan bone graft dengan serbuk cangkang cue yang diukur menggunakan Software ImageJ dapat dilihat pada Tabel 2.

Integrated density sekeliling implan yang konstan pada kelompok P2 mengindikasikan tidak terjadinya penolakan material implan terhadap jaringan tulang sekelilingnya. Material implan harus memberikan respons positif terhadap lingkungan biologis sekitarnya, tidak menimbulkan sitotoksisitas dan tahan terhadap 

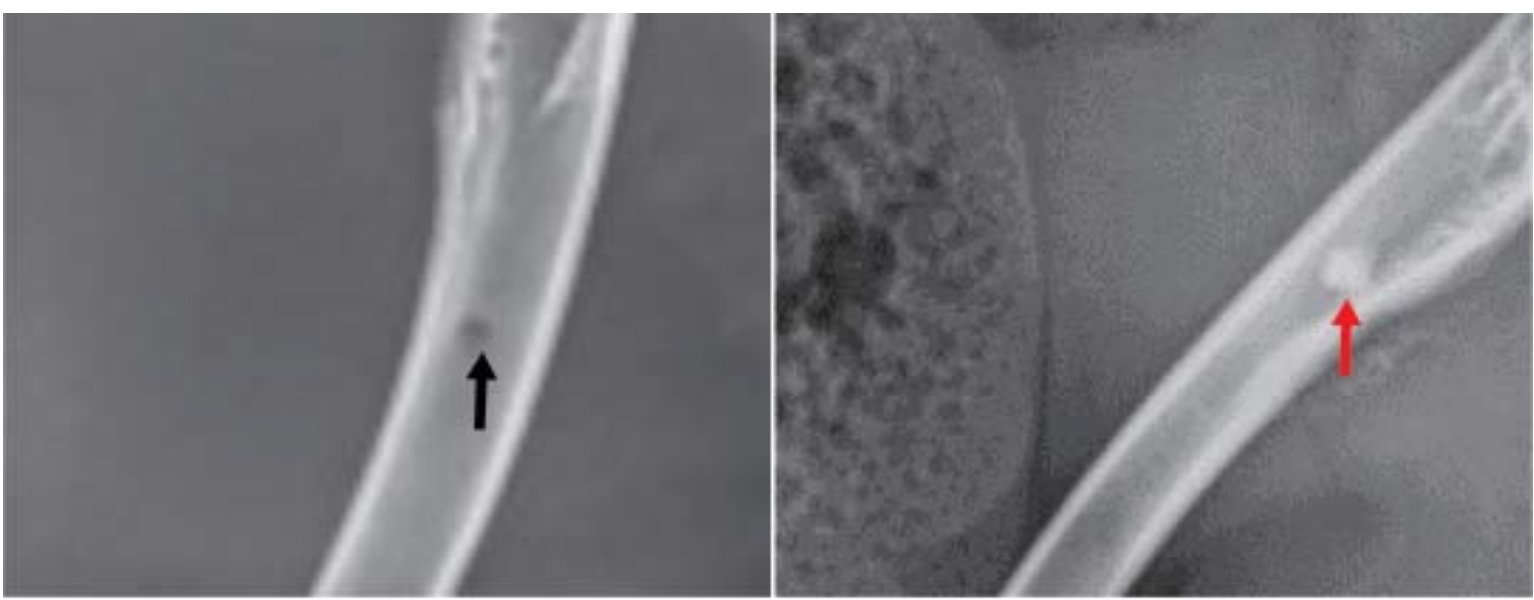

Gambar 2. Hasil rontgent tulang femur kelinci pada hari pengamatan ke-15 kelompok P1 (A) dan kelompok P2 (B). Area defek tulang yang diinfiltrasi $\mathrm{NaCl}$ 0,9\% dibiarkan sembuh sendiri ('!) tampak berwarna hitam (radiolucent), sedangkan area defek tulang yang diimplan dengan bone graft serbuk cangkang cue ('!) tampak berwarna putih (radiopaque)

Tabel 2. Integrated density sekeliling implan

\begin{tabular}{lcc}
\hline $\begin{array}{l}\text { Waktu Penga- } \\
\text { matan (Hari) }\end{array}$ & \multicolumn{2}{c}{ Kelompok } \\
\cline { 2 - 3 } & $\mathrm{P} 1$ & $\mathrm{P} 2$ \\
\hline 15 & $141,93 \pm 4,70^{\mathrm{a}^{*}}$ & $179,20 \pm 2,93^{\mathrm{a}+}$ \\
30 & $146,86 \pm 4,70^{\mathrm{ab}^{*}}$ & $183,87 \pm 2,93^{\mathrm{a}+}$ \\
45 & $158,67 \pm 4,70^{\mathrm{bc}^{*}}$ & $183,93 \pm 2,93^{\mathrm{a}+}$ \\
60 & $165,06 \pm 4,70^{\mathrm{c}^{*}}$ & $186,90 \pm 2,93^{\mathrm{a}+}$ \\
\hline
\end{tabular}

Keterangan: Kelompok perlakuan I (P1) diinfiltrasi $\mathrm{NaCl}$ 0,9\% dan kelompok perlakuan II (P2) diberikanserbukcangkang cue sebanyak 0,25 g. Angka yang diikuti superskrip berbeda $\left({ }^{*}+\right)$ pada baris yang sama menunjukkan perbedaan signifikan $(\mathrm{P}<0,05)$ antar kelompok perlakuan. Angka yang diikuti superskrip berbeda pada kolom yang sama (a-b-c) menunjukkan perbedaan signifikan diantara waktu pengamatan $(\mathrm{P}<0,05)$

korosi, dengan kata lain bersifat biokompatibel. Korosi dapat menyebabkan perubahan pada jaringan sekitar seperti permukaan jaringan yang kasar atau pun pelepasan elemen yang dapat menimbulkan reaksi toksik pada jaringan. Jaringan yang berdekatan dengan implan akan tampak berubah warna bahkan nekrosis. Pada tulang, perubahan-perubahan tersebut akan menyebabkan berkurangnya kepadatan tulang sehingga integrated density-nya menurun (Manivasagam et al., 2010; Saini et al., 2015).

\section{Gambaran Klinis Otot}

Pengamatan otot dan tulang sekeliling implan kedua kelompok perlakuan menunjukkan serabut otot dalam keadaan baik, mengandung mioglobin (normal) yang disajikan pada Gambar 4. Jaringan otot yang melekat dengan implan tampak sama baik teksturya maupun warnanya dengan otot sekitarnya. Karakteristik material implan dapat dikatakan biokompatibel apabila bersifat non-iritan dan tidak menimbulkan dampak negatif lainnya terhadap jaringan sekitar (Oryan dan Alidadi, 2017). Pada area implan, defek tulang sudah tertutup. Tahap pertama kesembuhan tulang ialah tulang yang patah kembali ke posisi semula dan stabil, sedangkan tahap kedua saat defek tulang tertutup dengan tulang yang baru (Pippi, 2017).

\section{Gambaran Histopatologi Otot dan Tulang}

Gambaran histologi otot sekeliling implan kelompok P1 menunjukkan struktur yang kompak dan teratur, ruang antar otot normal, jaringan ikat intervasikuler dan tidak ditemukan nekrosis beserta respons inflamasi (Gambar 5A). Struktur otot sekeliling implan kelompok P2 menunjukkan susunan yang tidak teratur, otot tidak kompak, ruang antar otot melebar dan terjadi disosiasi serat-serat otot. Terdapat respons inflamasi yang ditandai dengan infiltrasi sel-sel radang di jaringan, proliferasi jaringan ikat dan nekrosis serat otot (Gambar 5B). Skoring pengamatan histopatologi otot disajikan pada Tabel 3 . 

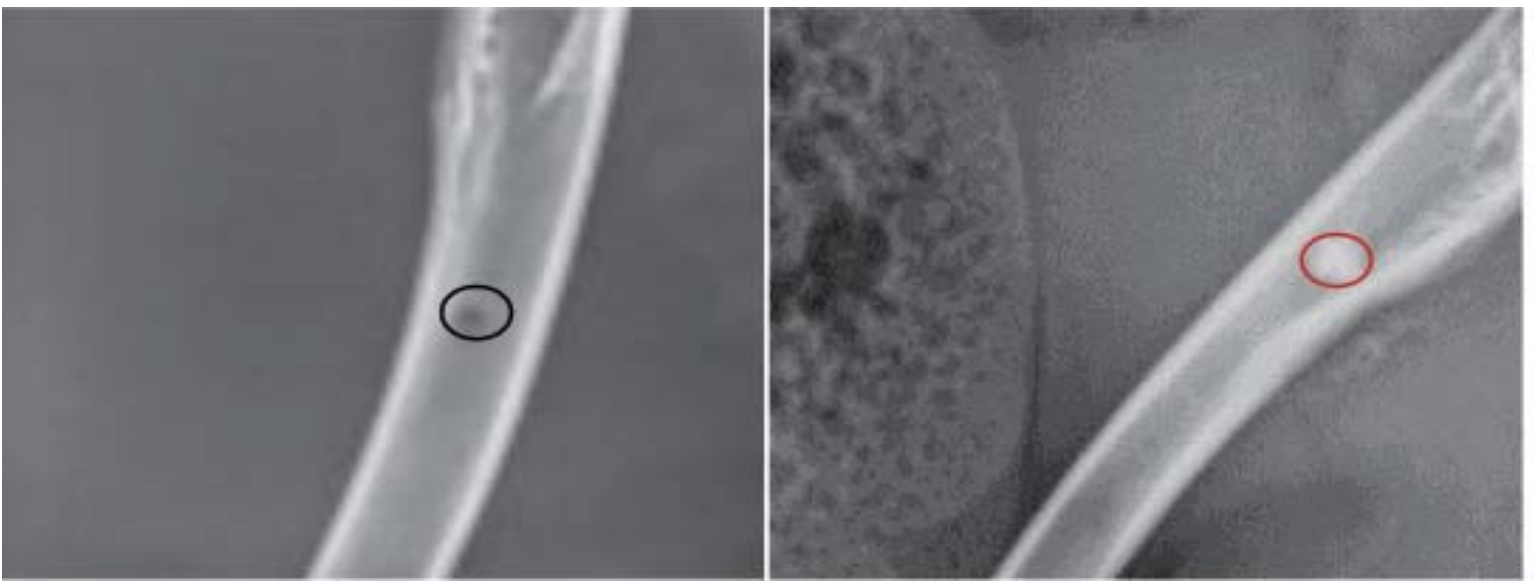

Gambar 4. Hasil rontgent tulang femur kelinci pada hari pengamatan ke-15 kelompok P1 (A) dan

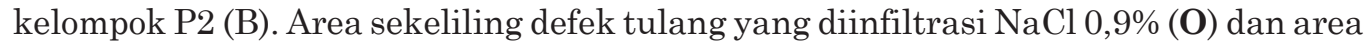
sekeliling defek tulang yang diimplan dengan bone graft serbuk cangkang cue (O)


Gambar 5. Pengamatan secara klinis otot dan tulang sekeliling implan. Otot (*) dan tulang ('!) pada kelompok P1 (A) serta otot (*) dan tulang ('!) pada kelompok P2 (B) tidak mengalami perubahan patologi

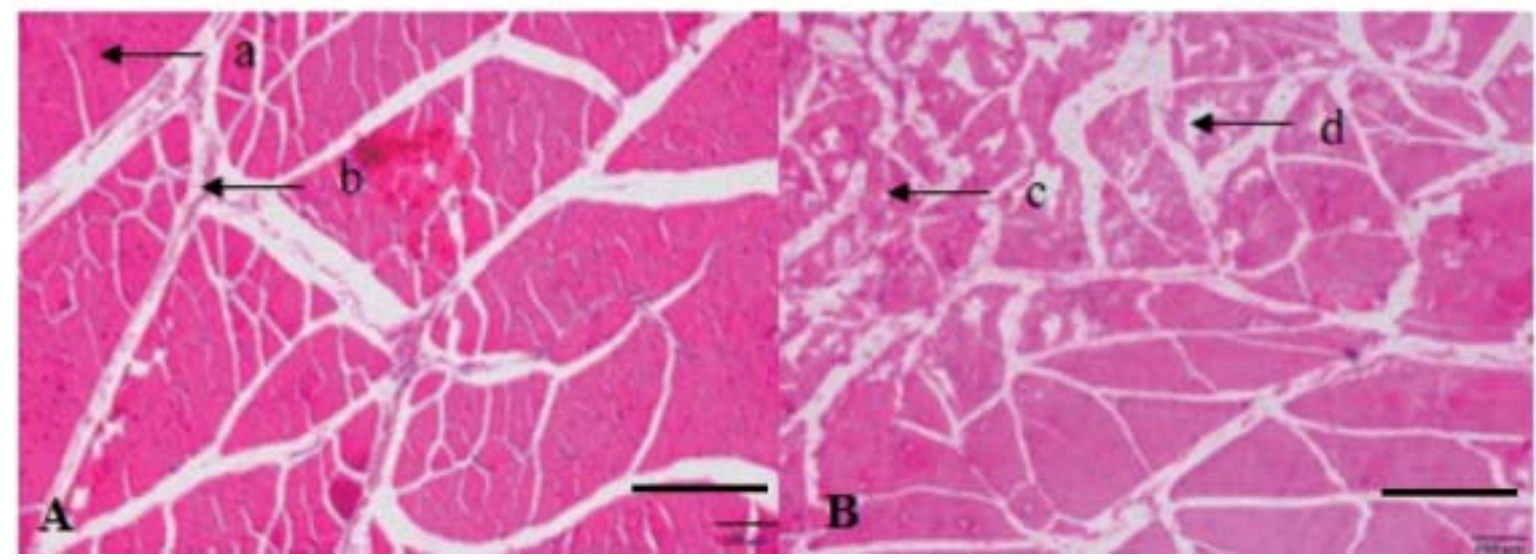

Gambar 6. Gambaran histologis otot kelompok P1 (A) dan kelompok P2 (B). (a) Serat otot kompak, (b) jaringan ikat intervasikuler; (c) serat otot tidak kompak; dan (d) Nekrosis serat otot. Pewarnaan HE. 
Tabel 3. Skoring pengamatan histopatologi otot sekitar implan

\begin{tabular}{lcc}
\hline $\begin{array}{l}\text { Parameter } \\
\text { yang Diamati }\end{array}$ & $\begin{array}{c}\text { Kelompok } \\
\text { P1 }\end{array}$ & $\begin{array}{c}\text { Kelompok } \\
\text { P2 }\end{array}$ \\
\hline Kepadatan otot & ++ & + \\
Respon inflamasi & - & ++ \\
di sekitar implan & & + \\
Nekrosis & - & + \\
Jaringan ikat & + & + \\
\hline
\end{tabular}

Keterangan: Kelompok perlakuan I (P1) diinfiltrasi $\mathrm{NaCl}$ 0,9\% dan kelompok perlakuan II (P2) diberikan serbukcangkang cue sebanyak 0,25 g. *Anotasi skoring (-) tidak ditemukan; (+) sedikit; (++) banyak

Hasil pengamatan histologis tulang kelompok P1 menunjukkan gambaran tulang normal yang disajikan pada Gambar 6A. Tidak ditemukan proliferasi jaringan ikat pada defek dan tidak terdapat reaksi inflamasi dan nekrosis. Proliferasi jaringan ikat pada implan, pertumbuhan tulang baru, dan proliferasi bone marrow ditemukan pada kelompok P2. Terdapat infiltasi sel radang, daerah nekrosis dan neovaskularisasi dalam jumlah sedikit. Histologis tulang kelompok P2 dapat dilihat pada Gambar 6B, sedangkan skoring pengamatan histopatologi tulang disajikan pada Tabel 4 .

Penelitian ini bertujuan untuk melihat reaksi jaringan terhadap serbuk cangkang cue yang diimplan pada tulang femur kelinci (sebagai model fraktur/yang dibuatkan defek pada tulangnya). Metode ini merupakan salah satu cara untuk menguji biokompatibilitas material
Tabel 4. Skoring pengamatan histopatologi tulang sekitar implan

\begin{tabular}{lcc}
\hline $\begin{array}{l}\text { Parameter } \\
\text { yang Diamati }\end{array}$ & $\begin{array}{c}\text { Kelompok } \\
\text { P1 }\end{array}$ & $\begin{array}{c}\text { Kelompok } \\
\text { P2 }\end{array}$ \\
\hline $\begin{array}{l}\text { Proliferasi jaringan } \\
\text { ikat pada implan }\end{array}$ & - & ++ \\
$\begin{array}{l}\text { Pertumbuhan tulang } \\
\text { baru di sekitar implant }\end{array}$ & - & ++ \\
Proliferasi bone marrow & - & ++ \\
Neovaskularisasi & - & + \\
$\begin{array}{l}\text { Reaksi inflamasi } \\
\text { di sekitar implan }\end{array}$ & - & + \\
Nekrosis & - & + \\
\hline
\end{tabular}

Keteranga: Kelompok perlakuan I (P1) diinfiltrasi $\mathrm{NaCl}$ 0,9\% dan kelompok perlakuan II (P2) diberikan serbukcangkang cue sebanyak 0,25 g. *Anotasi skoring (-) tidak ditemukan; (+) sedikit; $(++)$ banyak

implan, yaitu toksisitas lokal terhadap jaringan sekitar (Suvaneeth dan Nair, 2018). Kelompok P1 sebagai perbandingan kontrol (tanpa implan) dengan kelompok P2 (implan dengan serbuk cangkang cue). Infiltrasi sel-sel radang yang ditemukan semakin lama, semakin menurun pada proses kesembuhan tulang. Tingkat peradangan yang dialami ditandai dengan banyaknya produk radang yang ditemukan (Claes et al., 2012).

Neovaskularisasi dan pertumbuhan tulang baru pada tulang kelompok P2 mengindikasikan bahwa material implan bersifat osteokonduktif dan memicu proses diferensiasi stem cell mesenkim menjadi kondroblas dan osteoblast

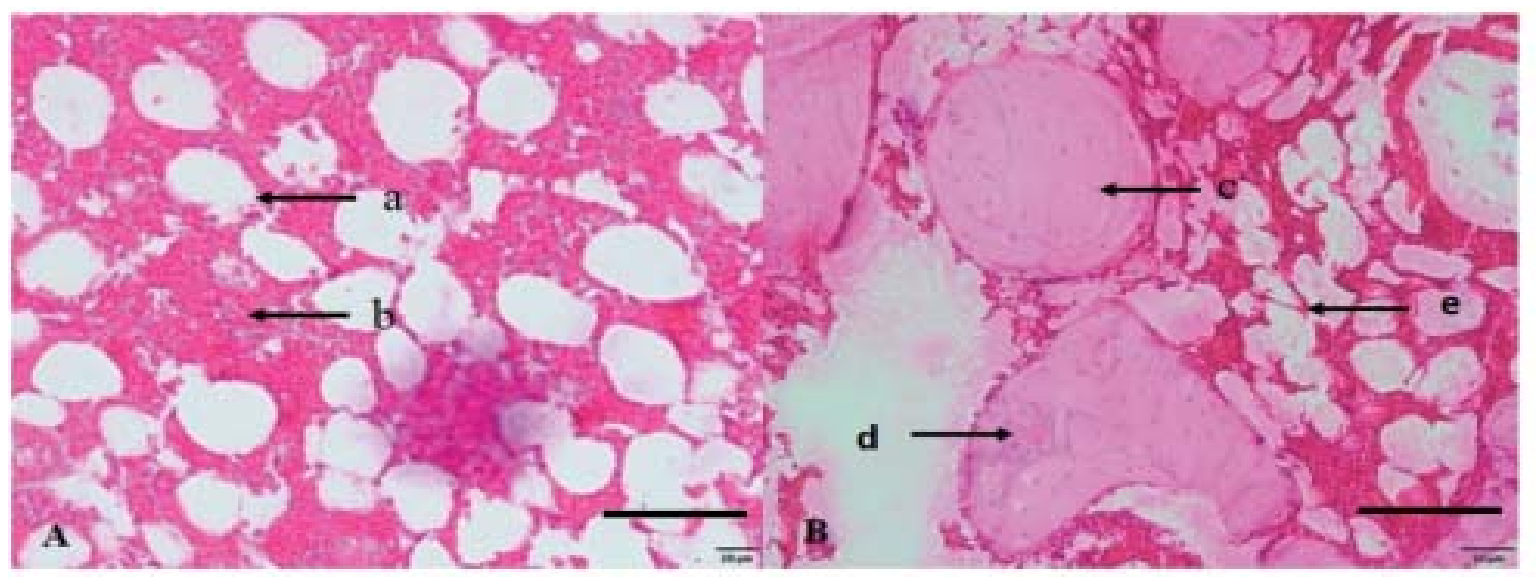

Gambar 7. Gambaran histologis tulang kelompok P1 (A) dan kelompok P2 (B) : (a) sel adiposa pada bone marrow, (b) sel-sel hematopoetik pada bone marrow, (c) pertumbuhan tulang baru, (d) jaringan ikat, dan (e) proliferasi bone marrow. Pewarnaan HE 
sehingga terbentuk tulang baru (Yi et al., 2016; Pellegrini et al., 2017). Namun, dalam penelitian ini masih ditemukan area nekrosis dan infiltrasi sel-sel radang baik pada tulang maupun otot kelompok P2. Menurut Takagi (2001), implan yang dimasukkan ke dalam tubuh akan berintegrasi dengan jaringan dan terpapar oleh cairan ekstraseluler. Integrasi tersebut akan memicu proses korosi atau ionisasi dari implan sehingga menimbulkan respons terhadap jaringan berupa reaksi ringan.

Pada penelitian ini, nekrosis dan infiltrasi sel-sel radang yang ditemukan sedikit dan tidak massif. Otot tidak menunjukkan reaksi fibrosis, inflamasi, dan nekrosis pada waktu 2,5 bulan pascaimplantasi. Hal ini terjadi karena kemampuan jaringan otot beregenerasi dengan sangat cepat (Santonen et al., 2010; Primadiani et al., 2016). Selain itu, adanya pengaruh kandungan unsur lain dari serbuk cangkang cue yang belum diketahui diduga dapat memengaruhi proses kesembuhan tulang. Cangkang cue memiliki pori-pori yang mampu mengabsorpsi dan mengikat ion logam yang ada di lingkungannya (Jamil dan Ridwan, 2019). Sebagian biota laut membutuhkan logam berat untuk pertumbuhan dan perkembangan hidup, khususnya dalam hal pembentukan hemosianin dalam sistem darah dan enzimatik. Kandungan logam yang bersifat toksik dapat menyebabkan kerusakan jaringan berupa erosi, degenerasi dan nekrosis (Berniyanti, 2018). .

\section{SIMPULAN}

Cangkang cue mengandung mineral yang mirip dengan tulang yaitu kalsium. Pengamatan klinis dan histopatologis otot dan tulang sekitar implan menunjukkan serabut otot baik, mengandung mioglobin dan tidak ditemukan perubahan patologis yang parah. Densitas area implan bertahan sampai akhir waktu pengamatan. Hal ini menunjukkan serbuk cangkang cue memiliki biokompatibilitas yang baik dan berpotensi untuk dikembangkan menjadi bahan hidroksiapatit alami (bone graft).

\section{UCAPAN TERIMA KASIH}

Penulis mengucapkan terima kasih kepada Rektor Universitas Syiah Kuala dan DRPM Kementerian Pendidikan dan Kebudayaan Republik Indonesia atas dana Riset Penelitian
Tesis Magister Nomor 53/UN11.2.1/PT.01.03/ DRPM/2020.

\section{DAFTAR PUSTAKA}

Agustina R, Ali S, Yulianda F, Suhendrayatna. 2017. Akumulasi logam berat pada siput (Faunus ater) dan struktur populasinya di daerah aliran sungai Krueng Reuleng, Kecamatan Leupung, Kabupaten Aceh Besar. Program Pascasarjana Unsyiah. Prosiding Semiar Nasioal Pascasarjana Unsyiah. Banda Aceh. 2017. Hlm. 1-7.

Alif MF, Arief S, Yunita. 2017. Penjernihan air gambut dengan hidroksiapatit yang disintesis dari limbah cangkang Langkitang (Faunus ater). J Ris Kim 6(3): 40-50.

Asfi WM, Ilza M, Karnila R. 2019. Pengaruh proses pengolahan berbeda terhadap kandungan proksimat pada siput Langkitang (Faunus ater). Jurnal Perikanan dan Kelautan 24(2): 1-10.

Atakisi E, Atakisi O, Topcu B, Uzun M. 2009. Effects of therapeutic dose of ivermectin on plasma nitric oxide and total antioxidant capacity in rabbits. Eur Rev Med Pharmacol Sci 13: 425-429.

Berniyanti T. 2018. Biomarker Toksisitas: Paparan Logam Tingkat Molekuler. Surabaya. Airlangga University Press.

Claes L, Recknagel S, Ignatius A. 2012. Fracture healing under healthy and inflammatory conditions. Nat Rev Rheumatol 8: 133-143.

Dahiya UR, Mishra S, Bano S. 2019. Application of bone substitutes and its future prospective in regenerative medicine. IntechOpen 1-20.

Einhorn TA, Gerstendfeld LC. 2014. Fracture healing: mechanisms and interventions. Nat Rev Rheumatol 164: 1-10.

Fischer V, Haffner-Luntzer M, Amling M, Ignatius A. 2018. Calcium and vitamin D in bone fracture healing and post-traumatic bone turnover. Eur Cells Mater 35: 365-385.

Fitriawan M. 2014. Sintesis hidroksiapatit berbahan dasar tulang sapi dengan metode presipitasi sebagai kandidat pengganti graft. Universitas Negeri Semarang. Prosiding Seminar Nasonal Mahasiswa Fisika. Semarang. 20 Desember 2014. Hlm. 1-5. 
Jamil NN, Ridwan. 2019. Pemanfaatan biomassa cangkang Langkitang (Faunus ater) sebagai biosorben logam berat krom pada limbah cair. J Aerasi 1(1): 1-6.

Manivasagam G, Dhinasekaran D, Rajamanickam A. 2010. Biomedical implants: corrosion and its prevention - a review. Recent Patents on Corrosion Science 2: 4054.

Mo KH, Alengaram UJ, Jumaat MZ, Lee SC, Goh WI, Yuen CW. 2018. Recycling of seashell waste in concrete: a review. Const and Build Mat 162: 751-764.

Nordin BE. 1997. Calcium and osteoporosis. Nutrition 13: 664-686.

Oryan A, Alidadi S. 2017. Chapter 1: application of bioceramics in orthopaedics and bone tissue engineering. Bone Regeneration. www.avidscience.com. Diakses pada 18 April 2020.

Palacios C. 2006. The role of nutrients in bone health, from A to Z. Crit Rev Food Sci Nutr 46: 621-628.

Pellegrini GG, Gonzales-Chaves MMS, Orzuza R, Zeni SN. 2017. Preliminary study on the biocompatibility and osteoconductive properties of a new bovine bone graft. Actual Osteol 13(2): 116-124.

Pippi R. 2017. Review: post-surgical clinical monitoring of soft tissue wound healing in periodontal and implant surgery. Int $\mathrm{J} \mathrm{Med}$ Sci 14(8): 721-728.

Plumb DC. 2018. Plumb's, Veterinary Drug Handbook. $9^{\text {th }}$ Ed. Wisconsin. PharmaVet Inc.

Primadiani IV, Mardiati SM, Tana S. 2016. Struktur histologi otot femur kelinci (Lepus $s p$.) setelah perlakuan implantasi material stainless steel Aisi 3161 selama 2,5 bulan. Buletin Anatomi dan Fisiologi 24(1): 27-33.

Saini M, Singh Y, Arora P, Arora V, Jain K. 2015. Implant biomaterials: a comprehensive review. World J Clin Cases 3(1): 52-57.
Santonen T, Stockmann JH, Zitting A. 2010. Review on toxicity of stainless steel. Helsiki. Finnish Institute of Occupational Health. Hlm. 1-87. ISBN 978-952-261-039-3

Solomon L, Warwick D, Nagayam S. 2010. Apley's System of Orthopaedics and Fractures. $9^{\text {th }} \mathrm{Ed}$. London. Hachette UK Company.

Suvaneeth P, Nair ND. 2018. Biomaterials and biocompatibility. World J Pharm Res 7(10): 161-171.

Suryanisngsih, Said I, Rahman N. 2018. Analisis kadar kalsium (Ca) dan besi (Fe) dalam kangkung air (Ipomeae aquatica Forsk) dan kangkung darat (Ipomeae reptan Forsk) asal Palu. J Akademika Kim 7(3): 130-135.

Takagi M. 2001. Bone-implant interface biology, foreign body reaction and periprosthetic osteolysis in artificial hip joint. J Clin Exp Hematopathol 40: 78-80.

Thrall DE. 2013. Textbook of Veterinary Diagnostic Radiology. $6^{\text {th }}$ Ed. Carolina (US). Elsevier Inc. Hlm. 74-85.

Wijaya TK, Hadiwidodo M, Purwono. 2017. Studi penurunan TSS, turbidity dan COD dengan menggunakan kitosan dari limbah cangkang sumpil (Faunus ater) sebagai nano biokoagulan dalam pengolahan limbah cair PT. Phapros Tbk Semarang. Indonesia J Urban Environ Technol 6(1): 1-7.

Wirata IW, Purbantoro SD, Sudimartini LM, Gunawan IWNF, Dharmayudha AAO, Pemayun IGAGP. 2018. Radiographic evaluation of rabbit femur implanted Bali cattle bone graft. Jurnal Veteriner 19(3): 439-445.

Yi H, Rehman UF, Zhao C, Liu B, He N. 2016. Recent advances in nano scaffolds for bone repair. Bone Res 4(1): 40-54. 